\title{
Rheological Measurement of Polymeric Composites before and after UV Degradation
}

\section{Lenka Markovičová, Viera Zatkalíková, Milan Uhríčik, Tatiana Liptáková}

Faculty of Engineering, Department of Materials Engineering, University of Zilina, Univerzitna 8215/1, 010 26 Zilina, Slovakia, e-mail: lenka.markovicova@fstroj.uniza.sk

The aim of this paper is the comparison of selected rheological properties of polymeric composites with glass fibers materials before and after exposure in UV box. Rate and depth of degradation induced by the environment were evaluated by Frequency Sweep Test, which monitors changes in viscoelastic properties of polymers with respect to their molecular structure and their behavior in thermoplastic processes. Degradation process resulted in changes of complex dynamic viscosity, storage and loss modulus, changes in molecular weight and its distribution. UV radiation is intense degradation factors affecting the change in the structure and properties of polymers - the polymer matrix gradually degrades by UV radiation, the viscosity of the composites decreases, the COP is moved to lower angular frequencies with increasing molar mass.

Keywords: polyamide, frequency sweep test, UV degradation, microstructure, glass fibers

\section{Acknowledgement}

The research was supportedpartially by Scientific Grant Agency of Ministry of Education, Science and Sport of Slovak Republic and Slovak Academy of Science, grant VEGA No. 1/0123/15, No. 1/0533/15 and grant KEGA No. 049ŽU$4 / 2017$.

\section{References}

[1] ZWEBEN, C. (1998). Composite Materials and Mechanical Design. Mechanical Engineer's Handbook, $2^{\text {nd }}$ ed., Myer Kutz, Ed., John Willey \& Sons, Inc., New York.

[2] High Performance Composites Source Book 2001, Ray Publishing, www.hpcomposites.com.

[3] The Composites Materials Handbook-Mil 17, Technomic Publishing Co. Inc., Lancaster, PA, 1999.

[4] BÍLEK, O., ŽALUDEK, M., ČOP, J. (2016). Cutting Tool Performance in End Milling of Glass Fiber-Reinforced Polymer Composites. Manufacturing Technology, Vol. 16, No. 1, ISSN 1213-2489, 12-16.

[5] BRYDSON, J.A. (1995). Plastic Materials, 6/e, Butterworth-Heinemann, Oxford, p. 507.

[6] BERINS, M.L. (1991). Plastic Engineering Handbook of the Society of the Plastic Industry, 5/e, Chapman and Hall, New York, p. 65.

[7] CARRAHER, C.E. (1996). Polymer Chemistry, An Introduction, 4/e, Marcel Dekker, Inc., New York, p. 53.

[8] RAZ, K, ZAHALKA, M., CHAVAL, Z, (2017). Injection molding quality improvement by advanced virtual simulations, Manufacturing Technology, vol. 17, 2017, ISSN 1213-2789, 79-83.

[9] DENISOV, E.T. (1982). In: Scott G. Editor. Developments in polymer stabilization, Vol. 5, London: Applied Science, p. 23-40.

[10] CARRAHER, Ch.E. Jr. (2007). Introduction to Polymer Chemistry, Taylor and Francis Group, ISBN 0-84937047-2, USA.

[11] WOLLNY, K. (2006). Comparison of a propylene reinceforced with glass fiber and pure polypropylen over a temperature range from -150 to $+180^{\circ} \mathrm{C}$, Anton Paar Germany $\mathrm{GmbH}$.

[12] MARKOVICOVA, L., ZATKAliKOVA, V., VASKO, A. (2016). Accelerated Aging of Polymeric Composites in Laboratory Conditions, Manufacturing Technology, vol. 6, No. 5, 2016, ISSN 1213-2489, 1033-1037.

[13] MEZGER, T.G. (2006). The Rheology Handbook, 2. Hannover: Vincentz Network, ISBN 3-87870-174-8, 299.

[14] VOJSOVIČOVÁ, M., LIPTÁKOVÁ, T., ZATKALÍKOVÁ, V.(2011). Rheological characteristic of thermoplastic polymer after degradation, In: Communications, Scientific Letters of the University of Zilina, Vol. 13, EDIS: Publishing Institution of Zilina University, ISSN 1335-4205, 32-35.

[15] LELOVICS, H., LIPTÁKOVÁ, T.(2010).Rheological properties of acrylic bone cement SmartSet巴HV, In: Communications, Scientific Letters of the University of Zilina, Vol. 12, EDIS: Publishing Institution of Zilina University, ISSN 1335-4205, 85-89. 
[16] YOUSIF, E. Et al. (2015). Viscoelastic, Spectroscopic and Microscopic Study of the Photo Irradiation Effect on the Stability of PVC in the Presence of Sulfamethoxazole Shiff's Bases, In: Polymers, vol.7, 2190-2204.

[17] GIJSMAN, P., MEIJERS, G., VITARELLI, G. (1999). Comparison of the UV-degradation chemistry of PP, PE, PA6 and PBT, Polymer degradation and stability, Vol. 65, 3, 433-441.

\section{Paper number: M201792}

Copyright (C) 2017. Published by Manufacturing Technology. All rights reserved. 